\title{
Hyperbaric Oxygen Therapy and Oxygen Compatibility of Skin and Wound Care Products
}

\author{
Stéphanie F. Bernatchez, ${ }^{1, *}$ Joseph Tucker, ${ }^{1}$ and Gwenael Chiffoleau ${ }^{2}$ \\ ${ }^{1} 3 \mathrm{M}$ Health Care Business Group, St. Paul, Minnesota. \\ ${ }^{2}$ WHA International, Inc. (WHA), Las Cruces, New Mexico.
}

Objective: Use test methods to assess the oxygen compatibility of various wound care products.

Approach: There are currently no standard test methods specifically for evaluating the oxygen compatibility and safety of materials under hyperbaric oxygen (HBO) conditions. However, tests such as the oxygen index (OI), oxygen exposure $(\mathrm{OE})$, and autogenous ignition temperature (AIT) can provide useful information.

Results: The OI test measures the minimum oxygen concentration that will support candle-like burning, and it was used to test 44 materials. All but two exhibited an OI equal to or greater (safer) than a control material commonly used in HBO. The OE test exposes each material to an oxygen-enriched atmosphere ( $>99.5 \%$ oxygen) to monitor temperature and pressure for an extended duration. The results of the $\mathrm{OE}$ testing indicated that none of the 44 articles tested with this method self-ignited within the $60^{\circ} \mathrm{C}, 3 \mathrm{~atm}$ pressurized oxygen atmosphere. The AIT test exposes materials to a rapid ramp up in temperature in HBO conditions at $3 \mathrm{~atm}$ until ignition occurs. Ten wound care materials and seven materials usually avoided in $\mathrm{HBO}$ chambers were tested. The AIT ranged from $138^{\circ} \mathrm{C}$ to $384^{\circ} \mathrm{C}$ for wound care products and from $146^{\circ} \mathrm{C}$ to $420^{\circ} \mathrm{C}$ for the other materials.

Innovation: This work provides useful data and recommendations to help develop a new standard approach for evaluating the HBO compatibility of wound care products to ensure safety for patients and clinicians.

Conclusion: The development of an additional test to measure the risk of electrostatic discharge of materials in $\mathrm{HBO}$ conditions is needed.

Keywords: hyperbaric oxygen therapy, wound care products, safety, test methods

\section{INTRODUCTION}

HYPERBARIC OXYGEN (HBO) therapy is used as an adjunct treatment to help healing for selected chronic wounds, among other conditions. The Undersea and Hyperbaric Medical So- ciety (uhms.org) is a well-recognized source of scientific information for hyperbaric medicine and produces a list of medical conditions that are appropriate for the use of this therapy, which is approved by the Food and

(C) Stéphanie F. Bernatchez, et al., 2017; Published by Mary Ann Liebert, Inc. This article is available under the Creative Commons License CC-BY-NC (http://creativecommons.org/licenses/by-nc/4.0). This license permits non-commercial use, distribution and reproduction in any medium, provided the original work is properly cited. Permission only needs to be obtained for commercial use and can be done via RightsLink.

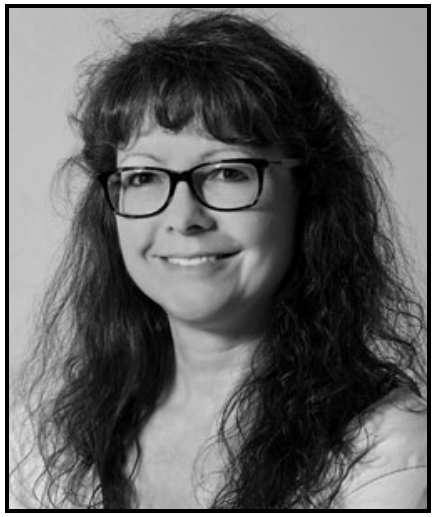

Stéphanie F. Bernatchez, PhD

Submitted for publication April 27, 2017. Accepted in revised form July 13, 2017.

*Correspondence: $3 \mathrm{M}$ Health Care Business Group, 3 M Center Building 270-3A-04, St. Paul, MN 55144-1000 (e-mail: sfbernatchez@mmm .com). 
Drug Administration (FDA) for several conditions. ${ }^{1}$ HBO therapy involves the exposure of the body to $100 \%$ oxygen at a pressure greater than $1 \mathrm{~atm}$ (usually between 1.5 and $3 \mathrm{~atm}$ ) for several treatment periods, each lasting between 1 and $2 \mathrm{~h}$. A typical course of treatment may involve 15-30 sessions. The period of treatment is on average from 2 to 4 weeks but may also last several months. The beneficial effects include intermittent correction of wound hypoxia, reduction of tissue edema, enhanced host immune response, improved wound metabolism, prevention of reperfusion injury, and induction of cytokines and their receptors. The history of hyperbaric therapy and the mechanisms of action have been reviewed in the literature. ${ }^{2,3}$

$\mathrm{HBO}$ is administered in various types of chambers (single-person or multi-person) combining an oxygen-enriched atmosphere and pressure elevation. These conditions inherently exhibit a fire risk, and many facilities request information on the oxygen compatibility of products used on HBO patients. Accidents have been fairly rare but when they happen, they can be fatal for the patient and staff involved, which is why this issue is taken very seriously. ${ }^{4-6}$ There are several American Society for Testing and Materials (ASTM) standards associated with best practices for oxygen use and test methods for material evaluation for oxygen service. ASTM G63 provides guidance for the selection of nonmetallic materials. Although many of its good practices are applicable to $\mathrm{HBO}$, as a general overview, the standard is likely too conservative for $\mathrm{HBO}$ applications. This standard is more orientated toward material selection for pressure components (e.g., valves, tubing) and higher pressure applications, not specifically for HBO wound dressings, many of which would not be considered oxygen compatible in higher pressure applications. ASTM test standards are performed either too high in pressure (such as ASTM G72, as historically performed, and ASTM G74) or too low in pressure (such as ASTM G125), as compared with HBO applications. The National Fire Protection Association has issued a handbook for healthcare facilities that covers potential ignition sources and guidance on materials that should be avoided in oxygen-filled chambers, ${ }^{7}$ and a few studies have been published describing tests that are intended to help determine the safety of specific devices in HBO chambers. ${ }^{8,9}$ Another study proposed a methodology (with a specific questionnaire) that consisted of identifying, quantifying, and managing the level of risk for any medical device before its use in a HBO chamber. ${ }^{10}$ However, there are currently no standard test methods specifically for evaluating oxygen compatibility of materials at $\mathrm{HBO}$ conditions. It is noteworthy that ASTM G72 ${ }^{11}$ was recently modified to permit testing in $\mathrm{HBO}$ conditions, however without specifically mentioning HBO. There is still no industry standard that provides a specific pass/fail criterion for evaluating oxygen compatibility of materials based on test data.

Tests such as the oxygen index (OI), oxygen exposure (OE), and autogenous ignition temperature (AIT) can provide information about the oxygen compatibility of wound care products. Our goal was to use these tests to evaluate a variety of wound care products that could likely be used by patients receiving $\mathrm{HBO}$ therapy to obtain information on the oxygen compatibility of these products. We hope to provide recommendations that are useful to develop a standard test method for medical products to be used in HBO chambers.

\section{CLINICAL PROBLEM ADDRESSED}

The risk of fire in HBO chambers is a very serious concern given the gravity of the incidents that have been reported. Many facilities request information about the oxygen compatibility of products used on $\mathrm{HBO}$ patients, and there is currently no industry standard providing a pass/fail answer for this determination. The HBO industry needs to make decisions on acceptable threshold values for materials deemed safe for use. This study intends to provide useful data and recommendations to help develop a needed standardized approach to evaluate the HBO compatibility of wound care products to ensure safety for patients and clinicians.

\section{MATERIALS AND METHODS}

\section{Materials tested}

Products such as tapes, dressings (including gauze, foam, alginate, hydrocolloid, and transparent film), compression bandages, and a film barrier (3 M, St. Paul, MN) were tested. Product names listed correspond to names in use at the time of the testing; some products have been discontinued or reformulated and given a modified name since then. A common cotton gauze (Johnson \& Johnson, New Brunswick, NJ) was included as a negative control (material considered safe in HBO chambers), and products generally avoided in HBO chambers (petrolatum, glycerin, nylon, and chemical hand warmers) were used as positive controls in the most promising assay to create a relevant range of results. Manufacturers are listed with each specific product later. The description of each test method that follows includes the specific list of materials tested, respectively. 
Oxygen index. The OI test (ASTM G125 ${ }^{12}$ ) measures the minimum oxygen concentration in a flowing mixture of oxygen and nitrogen (at atmospheric pressure) that will support candle-like burning of the sample material. This test is used to indicate relative flammability. The material is deemed flammable at the supplied oxygen concentration if: (1) the self-sustained burning of the sample propagates greater than $100 \mathrm{~mm}$ downward (against gas flow) from the top of the sample; or (2) the sample burns for a period lasting longer than $3 \mathrm{~min}$. In this assay, the higher the number, the safer the material, as it requires more oxygen to support burning.

A schematic of the OI Test System is shown in Fig. 1. The specified oxygen and nitrogen mixture was supplied to the bottom of the glass cylinder at a flow rate that produced a gas velocity of $4 \pm 1 \mathrm{~cm} / \mathrm{s}$ through the cylinder. The samples were prepared into test strips ( $52 \mathrm{~mm}$ wide by $140 \mathrm{~mm}$ long, with occasional small variations due to the product's actual size and design) and attached vertically to the sample holder. Once the glass cylinder atmosphere was purged with the gas mixture for a minimum of $30 \mathrm{~s}$, an igniter flame $(6-25 \mathrm{~mm}$ in

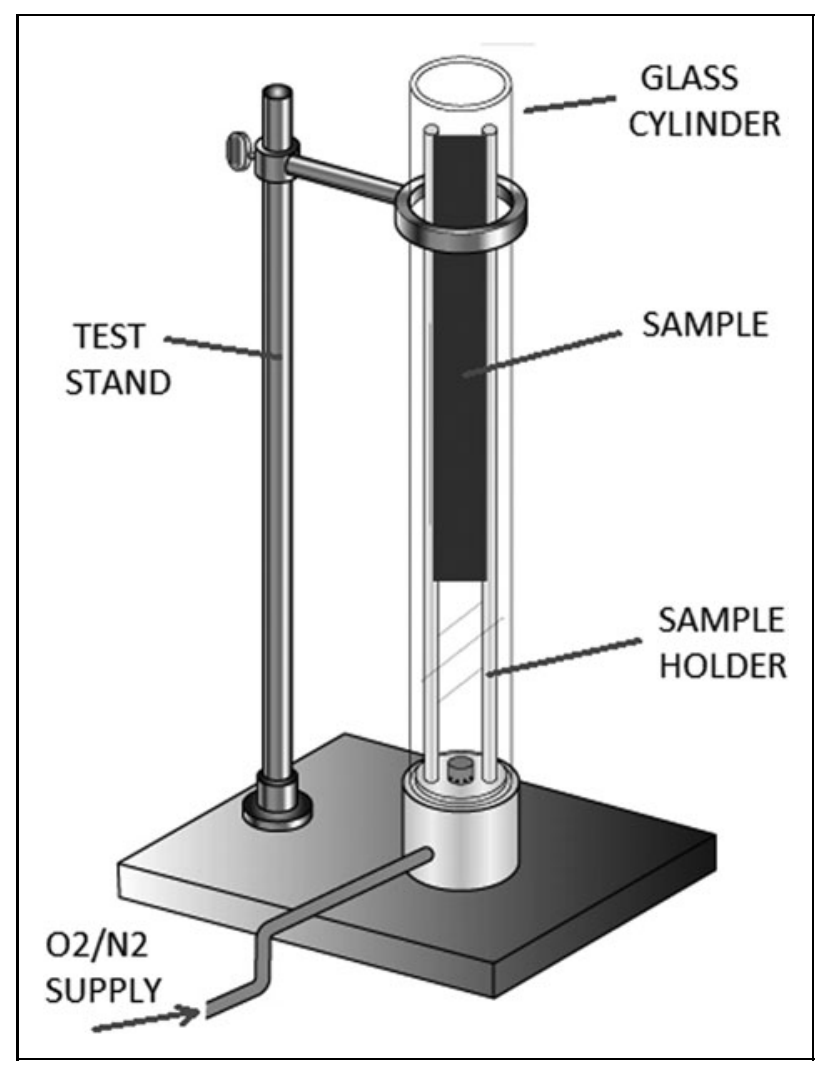

Figure 1. Schematic of 0 l test system. Ol, oxygen index. length when held vertically inside the cylinder atmosphere) was applied to the top edge of the sample by using a sweeping motion. The material was deemed flammable at the supplied oxygen concentration if: (1) the self-sustained burning of the sample propagated greater than $100 \mathrm{~mm}$ downward from the top of the sample or (2) the sample burned for a period lasting longer than $3 \mathrm{~min}$ (consistent with ASTM G125 ${ }^{12}$ ). For each test, the burn length, duration of burning, oxygen percentage, and oxygen flow rate were recorded. If the sample momentarily burned but stopped before the $100 \mathrm{~mm}$ of the sample was consumed or the burn time lasted less than $3 \mathrm{~min}$, a new sample was prepared and the oxygen concentration was increased until a burn result was observed. If the burn criteria were met, a new sample was prepared and the oxygen concentration was reduced until the minimum concentration for the sample was established. The testing was repeated, just below the OI, two more times at gas velocities that were slightly higher and lower than the standard flow rate.

\section{MATERIALS TESTED IN OI TEST Medical tapes}

The medical tapes were 2 inches wide and did not require any width adjustments. The length of these samples was cut to $\sim 5.5$ inches:

$3 \mathrm{M}^{\mathrm{TM}}$ Kind Removal Silicone Tape

$3 \mathrm{M}^{\mathrm{TM}}$ Micropore ${ }^{\mathrm{TM}}$ Surgical Tape

$3 \mathrm{M}^{\mathrm{TM}}$ Micropore $^{\mathrm{TM}}$ Plus Tape

$3 \mathrm{M}^{\mathrm{TM}}$ Transpore ${ }^{\mathrm{TM}}$ Surgical Tape

$3 \mathrm{M}^{\mathrm{TM}}$ Transpore ${ }^{\mathrm{TM}}$ White Surgical Tape

$3 \mathrm{M}^{\mathrm{TM}}$ Medipore $^{\mathrm{TM}} \mathrm{H}$ Soft Cloth Surgical Tape

$3 \mathrm{M}^{\mathrm{TM}}$ Durapore ${ }^{\mathrm{TM}}$ Surgical Tape

$3 \mathrm{M}^{\mathrm{TM}}$ Microfoam ${ }^{\mathrm{TM}}$ Surgical Tape

\section{Skin closures}

The skin closures were 1 inch wide and therefore, to achieve a 2 inch-wide sample, two strips were overlapped together. For each material, a 5 inch by $\sim 2$ inch sample was prepared.

$3 \mathrm{M}^{\mathrm{TM}}$ Steri-Strip ${ }^{\mathrm{TM}}$ Adhesive Skin Closures (Reinforced)

$3 \mathrm{M}^{\mathrm{TM}}$ Steri-Strip ${ }^{\mathrm{TM}}$ Antimicrobial Skin Closures $3 \mathrm{M}^{\mathrm{TM}}$ Steri-Strip ${ }^{\mathrm{TM}}$ Elastic Skin Closures

\section{Wound dressing materials}

The following samples were prepared by cutting them to $\sim 2$ inches $\times 5.5$ inches:

Johnson \& Johnson Rolled Gauze, Kling ${ }^{\circledR}$ Design (used as a negative control, as it is considered safe in HBO chambers)

$3 \mathrm{M}^{\mathrm{TM}}$ Tegaderm ${ }^{\mathrm{TM}}$ Non-Adherent Contact Layer $3 \mathrm{M}^{\mathrm{TM}}$ Tegaderm ${ }^{\mathrm{TM}}$ High Gelling Alginate Dressing 


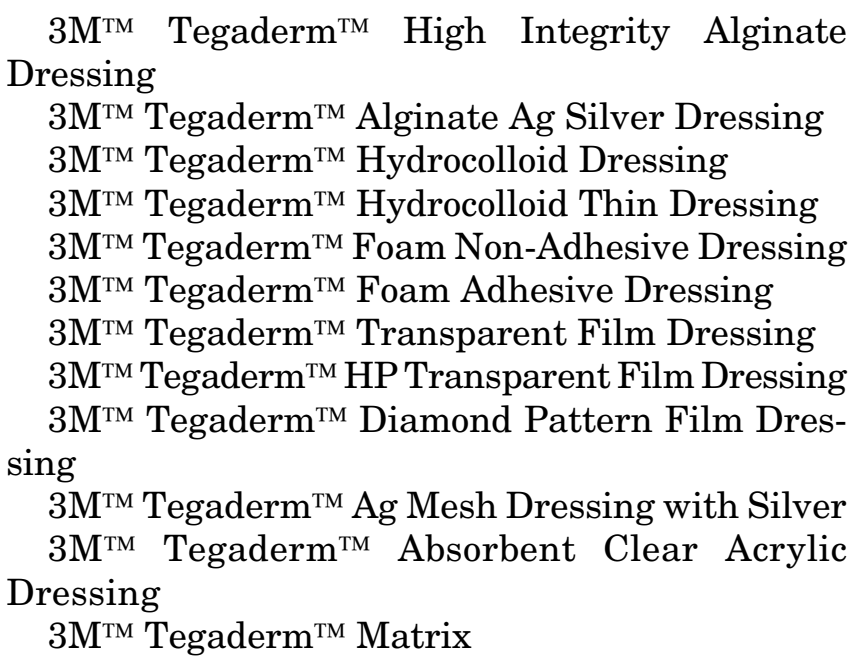

\section{Compression bandages and self-adherent wraps}

$3 \mathrm{M}^{\mathrm{TM}}$ Coban $^{\mathrm{TM}} 2$ Two-Layer Compression System (Compression Layer: outside layer without foam)

3M Coban 2 Two-Layer Compression System (Comfort Layer: inner layer with foam) $3 \mathrm{M}^{\mathrm{TM}}$ Coban $^{\mathrm{TM}}$ Self-Adherent Wrap (Tan) $3 \mathrm{M}^{\mathrm{TM}}$ Coban $^{\mathrm{TM}}$ LF Latex Free Self-Adherent Wrap (Tan)

\section{Gels, creams, and tinctures}

For each of these materials, a thin layer of each liquid sample was applied to its own fiberglass substrate and allowed to dry. Each fiberglass/sample was cut to $\sim 2$ inches by 5.5 inches.

$3 \mathrm{M}^{\mathrm{TM}}$ Tegaderm ${ }^{\mathrm{TM}}$ Hydrogel Wound Filler

$3 \mathrm{M}^{\mathrm{TM}}$ Cavilon $^{\mathrm{TM}}$ Durable Barrier Cream Fragrance Free

$3 \mathrm{M}^{\mathrm{TM}}$ Cavilon $^{\mathrm{TM}}$ No Sting Barrier Film

$3 \mathrm{M}^{\mathrm{TM}}$ Steri-Strip ${ }^{\mathrm{TM}}$ Compound Benzoin Tincture

\section{Multi-layer products}

These products contained multiple layers and were tested as a single material. The samples were prepared such that all layers were exposed to the flame simultaneously. The resulting OI was based on the sample layer with the lowest OI. This resulting OI was considered the OI for the product as a whole. For each of these multi-layer products, the samples were prepared by cutting along the top of the product, such that the top edge of the sample comprised all of the material layers. This allowed for all layers of the product to be exposed to the flame simultaneously during the test. Further, the other edges of each product were cut to provide samples that were $\sim 2$ inches by 5.5 inches.

$3 \mathrm{M}^{\mathrm{TM}}$ Tegaderm ${ }^{\mathrm{TM}}$ Silicone Foam Border Dressing $3 \mathrm{M}^{\mathrm{TM}}$ Tegaderm ${ }^{\mathrm{TM}}$ High Performance Foam NonAdhesive Dressing
$3 \mathrm{M}^{\mathrm{TM}}$ Medipore $+\mathrm{Pad}$ Soft Cloth Adhesive Wound Dressing

$3 \mathrm{M}^{\mathrm{TM}}$ Tegaderm ${ }^{\mathrm{TM}}+$ Pad Film Dressing with NonAdherent Pad

$3 \mathrm{M}^{\mathrm{TM}}$ Tegaderm ${ }^{\mathrm{TM}}$ Superabsorber Dressing

$3 \mathrm{M}^{\mathrm{TM}}$ Tegaderm ${ }^{\mathrm{TM}}$ CHG Chlorhexidine Gluconate I.V. Securement Dressing

$3 \mathrm{M}^{\mathrm{TM}}$ Tegaderm ${ }^{\mathrm{TM}}$ I.V. Film Dressing with Border

$3 \mathrm{M}^{\mathrm{TM}}$ Tegaderm ${ }^{\mathrm{TM}}$ I.V. Advanced Securement Dressing

$3 \mathrm{M}^{\mathrm{TM}}$ PICC/CVC Securement System (dressing component)

3M PICC/CVC Securement System (securement device component)

Oxygen exposure. The OE test (non-standard) exposes each material to an oxygen-enriched atmosphere ( $>99.5 \%$ oxygen) at $3 \mathrm{~atm}$ and $60^{\circ} \mathrm{C}$ for a minimum of $6 \mathrm{~h}$. Pressure and temperature data are recorded throughout, and sample mass is recorded pre- and post-test. Materials are monitored for self-ignition and for significant mass change.

The testing conditions were designed to simulate the worst-case material application environment while monitoring temperature and pressure changes to the atmosphere directly surrounding the sample and calculating any sample mass changes. The OE test contained each test sample in a $99.5 \%$ oxygen-enriched atmosphere at a constant $60^{\circ} \mathrm{C}$ and $3 \mathrm{~atm}$ pressure (absolute) for a minimum of $6 \mathrm{~h}$. Four J-Type thermocouples were installed in the test fixture and positioned over each test sample during the testing. The thermocouples inside the test chamber were placed $\sim 0.5$ inches above the test samples. The test sample mass was recorded before being installed inside the test chamber.

The OE testing was performed in a stainless steel test chamber. The OE test chamber is shown in Fig. 2. The custom-made test fixture is shown in Fig. 2. Samples were photographed and weighed, then placed four at a time on the test fixture and within the test chamber for each exposure test. Six "cycle-purges" of the test chamber with medicalgrade oxygen (greater than 99.5\% concentration) were performed. This was done according to ASTM G124-10 ${ }^{13}$ Section 13 "Conditioning" procedure to ensure that the original atmosphere in the chamber ( $\sim 20.9 \%$ oxygen) was less than $0.01 \%$ before testing. The temperature controller was enabled and once the temperature reached $\sim 60^{\circ} \mathrm{C}$, the time was noted as the "test start time." Temperature and pressure data were logged to a computer data file. After $6 \mathrm{~h}$, the test chamber was vented and the test fixture was removed. Samples were photographed and weighed, and observations were made 

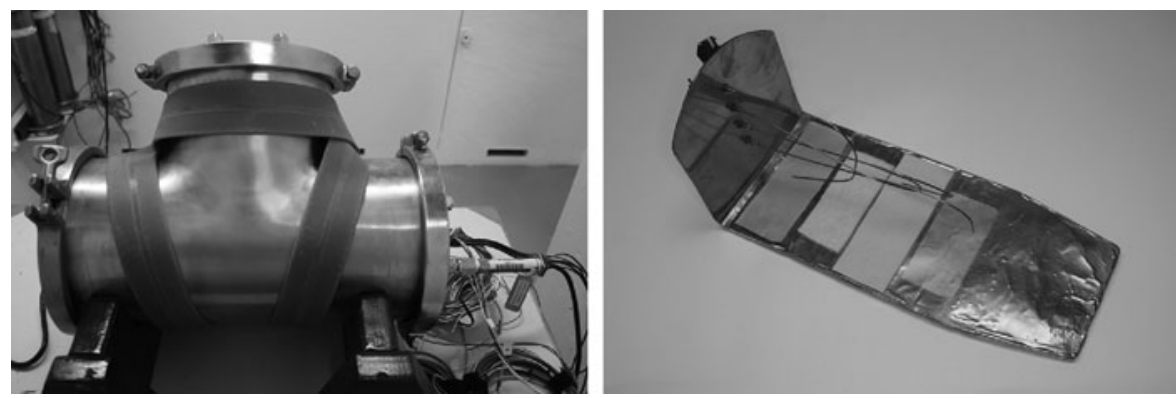

Figure 2. Left. WHA oxygen exposure test chamber; Right. Test fixture for mounting samples within the chamber.

of the state of the sample materials for signs of thermal activity.

\section{MATERIALS TESTED IN OE TEST}

A test sample size of $\sim 2$ inches by 5 inches was chosen for each product. The actual test article sizes varied depending on actual product dimensions. The details for the sample preparation for each material are as follows:

\section{Medical tapes}

The width of these products did not require any adjustments. The lengths of these samples were cut to $\sim 5$ inches:

$3 \mathrm{M}^{\mathrm{TM}}$ Kind Removal Silicone Tape

$3 \mathrm{M}^{\mathrm{TM}}$ Micropore $^{\mathrm{TM}}$ Surgical Tape

$3 \mathrm{M}^{\mathrm{TM}}$ Micropore $^{\mathrm{TM}}$ Plus Tape

$3 \mathrm{M}^{\mathrm{TM}}$ Transpore ${ }^{\mathrm{TM}}$ Surgical Tape

$3 \mathrm{M}^{\mathrm{TM}}$ Transpore ${ }^{\mathrm{TM}}$ White Surgical Tape

$3 \mathrm{M}^{\mathrm{TM}}$ Medipore $^{\mathrm{TM}} \mathrm{H}$ Soft Cloth Surgical Tape

$3 \mathrm{M}^{\mathrm{TM}}$ Durapore ${ }^{\mathrm{TM}}$ Surgical Tape

$3 \mathrm{M}^{\mathrm{TM}}$ Microfoam ${ }^{\mathrm{TM}}$ Surgical Tape

\section{Skin closures}

The skin closures were 1 inch wide, and the length was cut to $\sim 5$ inches. Though the width was only 1 inch, it was considered acceptable for this testing.

$3 \mathrm{M}^{\mathrm{TM}}$ Steri-Strip ${ }^{\mathrm{TM}}$ Adhesive Skin Closures (Reinforced)

$3 \mathrm{M}^{\mathrm{TM}}$ Steri-Strip ${ }^{\mathrm{TM}}$ Antimicrobial Skin Closures

$3 \mathrm{M}^{\mathrm{TM}}$ Steri-Strip ${ }^{\mathrm{TM}}$ Elastic Skin Closures

\section{Wound dressing materials and multi-layer products}

The following samples were prepared by cutting them in half to achieve samples that were $\sim 2$ inches $\times 5$ inches. As a general rule for dressing products, the product liner and frame were removed and not included in the exposure test; however, the paper label was included in the test, as well as the extra tape strips. The idea is to simulate what would be on a patient receiving $\mathrm{HBO}$ treatment. After application to a patient, the dressing liner and frame have been removed and discarded, but the paper label and extra tape strips could be used on the patient for labeling and additional securement.

Johnson \& Johnson Rolled Gauze, Kling Design (used as a negative control, as it is considered safe in HBO chambers)

$3 \mathrm{M}^{\mathrm{TM}}$ Tegaderm ${ }^{\mathrm{TM}}$ Non-Adherent Contact Layer $3 \mathrm{M}^{\mathrm{TM}}$ Tegaderm ${ }^{\mathrm{TM}}$ High Gelling Alginate Dressing

$3 \mathrm{M}^{\mathrm{TM}}$ Tegaderm ${ }^{\mathrm{TM}}$ High Integrity Alginate Dressing

$3 \mathrm{M}^{\mathrm{TM}}$ Tegaderm ${ }^{\mathrm{TM}}$ Alginate Ag Silver Dressing

$3 \mathrm{M}^{\mathrm{TM}}$ Tegaderm ${ }^{\mathrm{TM}}$ Hydrocolloid Dressing

$3 \mathrm{M}^{\mathrm{TM}}$ Tegaderm ${ }^{\mathrm{TM}}$ Hydrocolloid Thin Dressing

$3 \mathrm{M}^{\mathrm{TM}}$ Tegaderm ${ }^{\mathrm{TM}}$ Foam Non-Adhesive Dressing

$3 \mathrm{M}^{\mathrm{TM}}$ Tegaderm ${ }^{\mathrm{TM}}$ Foam Adhesive Dressing

$3 \mathrm{M}^{\mathrm{TM}}$ Tegaderm $^{\mathrm{TM}}$ High Performance Foam Non-

Adhesive Dressing

$3 \mathrm{M}^{\mathrm{TM}}$ Tegaderm $^{\mathrm{TM}}$ Transparent Film Dressing

$3 \mathrm{M}^{\mathrm{TM}}$ Tegaderm $^{\mathrm{TM}}$ HP Transparent Film Dressing

$3 \mathrm{M}^{\mathrm{TM}}$ Tegaderm ${ }^{\mathrm{TM}}$ Diamond Pattern Film Dressing

$3 \mathrm{M}^{\mathrm{TM}}$ Tegaderm ${ }^{\mathrm{TM}}$ Ag Mesh Dressing with Silver $3 \mathrm{M}^{\mathrm{TM}}$ Tegaderm $^{\mathrm{TM}}$ Absorbent Clear Acrylic Dressing

$3 \mathrm{M}^{\mathrm{TM}}$ Tegaderm ${ }^{\mathrm{TM}}$ Matrix

$3 \mathrm{M}^{\mathrm{TM}}$ Tegaderm ${ }^{\mathrm{TM}}$ Silicone Foam Border Dressing $3 \mathrm{M}^{\mathrm{TM}}$ Medipore +Pad Soft Cloth Adhesive Wound Dressing

$3 \mathrm{M}^{\mathrm{TM}}$ Tegaderm ${ }^{\mathrm{TM}}+\mathrm{Pad}$ Film Dressing with NonAdherent Pad

$3 \mathrm{M}^{\mathrm{TM}}$ Tegaderm ${ }^{\mathrm{TM}}$ Superabsorber Dressing

$3 \mathrm{M}^{\mathrm{TM}}$ Tegaderm $^{\mathrm{TM}}$ CHG Chlorhexidine Gluconate I.V. Securement Dressing

$3 \mathrm{M}^{\mathrm{TM}}$ Tegaderm $^{\mathrm{TM}}$ I.V. Film Dressing with Border

$3 \mathrm{M}^{\mathrm{TM}}$ Tegaderm ${ }^{\mathrm{TM}}$ I.V. Advanced Securement Dressing 
$3 \mathrm{M}^{\mathrm{TM}}$ PICC/CVC Securement System (dressing component)

$3 \mathrm{M}^{\mathrm{TM}}$ PICC/CVC Securement System (securement device component)

\section{Compression bandages and self-adherent wraps}

The width of these products did not require any adjustments. The lengths of these samples were cut to $\sim 5$ inches:

$3 \mathrm{M}^{\mathrm{TM}}$ Coban $^{\mathrm{TM}} 2$ Two-Layer Compression System (Compression Layer: outside layer without foam) $3 \mathrm{M}^{\mathrm{TM}}$ Coban $^{\mathrm{TM}} 2$ Two-Layer Compression System (Comfort Layer: inner layer with foam) $3 \mathrm{M}^{\mathrm{TM}}$ Coban $^{\mathrm{TM}}$ Self-Adherent Wrap (Tan) $3 \mathrm{M}^{\mathrm{TM}}$ Coban $^{\mathrm{TM}}$ LF Latex Free Self-Adherent Wrap (Tan)

\section{Gels, creams, and tinctures}

For each of these materials, a thin layer of each liquid sample was applied to its own fiberglass substrate and allowed to dry. Each fiberglass/ sample was cut to $\sim 2$ inches by 5 inches.

$3 \mathrm{M}^{\mathrm{TM}}$ Tegaderm ${ }^{\mathrm{TM}}$ Hydrogel Wound Filler

$3 \mathrm{M}^{\mathrm{TM}}$ Cavilon $^{\mathrm{TM}}$ Durable Barrier Cream Fragrance Free

$3 \mathrm{M}^{\mathrm{TM}}$ Cavilon ${ }^{\mathrm{TM}}$ No Sting Barrier Film

$3 \mathrm{M}^{\mathrm{TM}}$ Steri-Strip ${ }^{\mathrm{TM}}$ Compound Benzoin Tincture

Autogenous ignition temperature. The AIT test exposes materials to a rapid ramp up in temperature in $\mathrm{HBO}$ conditions at $3 \mathrm{~atm}$ until ignition occurs or until the maximum temperature set for the assay is reached. In this assay, the higher the number, the safer the material, as it will require a higher temperature to ignite.

The ASTM G72-09 ${ }^{14}$ test standard required a $200 \pm 30 \mathrm{mg}$ sample and a temperature ramp rate of $5^{\circ} \mathrm{C} \pm 1^{\circ} \mathrm{C} / \mathrm{min}$. The maximum temperature range implied by ASTM G72-0 $9^{14}$ was $425^{\circ} \mathrm{C}$. Based on experience (WHA and Committee G04 on Compatibility and Sensitivity of Materials in OxygenEnriched Atmospheres), the sample mass and temperature ramp rate could have significant influence on obtaining an ignition at low pressures. Therefore, two configurations per material were tested (samples of 20 and $200 \mathrm{mg}$, at a ramp rate of $100^{\circ} \mathrm{C} / \mathrm{min}$ ) in two replicates with USP oxygen $\left(\geq 99.5 \% \mathrm{O}_{2}\right)$ at a starting test pressure of $32 \pm 2 \mathrm{PSIG}$ and up to ignition or $600^{\circ} \mathrm{C}$ (which ever occurred first). Most materials produced a reasonable consistency (STD deviation $<10^{\circ} \mathrm{C}$ ), but two exhibited higher variability so we chose to use a conservative approach and reported the lowest AIT for each material.

Creams were sampled from containers; for products that exhibited different components (e.g., pad and adhesive), samples were prepared to include a portion of each component. The test chamber was designed to accommodate heating via an induction heater. The chamber was positioned inside an induction heater coil, and the axis of the chamber was orientated vertically. The bottom end cap accommodated a single gas port, which represented both the gaseous oxygen supply and vent path. The top end cap accommodated a thermocouple feed-through and included an internal rod for the test tube holder assembly. A schematic of the AIT Test System is shown in Fig. 3.

\section{MATERIALS TESTED IN AIT TEST}

At the time of the OI and OE testing, the lowpressure AIT test capability had not been developed. Due to the successful behavior of most materials in the OI and OE testing, a cross-section of products was selected for AIT testing to cover the main categories of tapes, wound dressing, and IV dressings.

\section{Wound care products typically allowed in $\mathrm{HBO}$ chambers}

Johnson \& Johnson Rolled Gauze, Kling Design $3 \mathrm{M}^{\mathrm{TM}}$ Micropore ${ }^{\mathrm{TM}}$ Surgical Tape

$3 \mathrm{M}^{\mathrm{TM}}$ Transpore ${ }^{\mathrm{TM}}$ White Surgical Tape

$3 \mathrm{M}^{\mathrm{TM}}$ Steri-Strip Adhesive Skin Closures (Reinforced)

$3 \mathrm{M}^{\mathrm{TM}}$ Tegaderm ${ }^{\mathrm{TM}}$ Hydrocolloid Thin Dressing

$3 \mathrm{M}^{\mathrm{TM}}$ Tegaderm ${ }^{\mathrm{TM}}$ HP Transparent Film Dressing $3 \mathrm{M}^{\mathrm{TM}}$ Tegaderm $^{\mathrm{TM}} \mathrm{Ag}$ Mesh Dressing with Silver $3 \mathrm{M}^{\mathrm{TM}}$ Coban $^{\mathrm{TM}}$ Self-Adherent wrap (Tan)

$3 \mathrm{M}^{\mathrm{TM}}$ Tegaderm ${ }^{\mathrm{TM}}$ Silicone Foam Border Dressing $3 \mathrm{M}^{\mathrm{TM}}$ Tegaderm $^{\mathrm{TM}}+$ Pad Film Dressing with NonAdherent Pad

\section{Products typically avoided in $\mathrm{HBO}$ chambers}

Glycerin-based cream (Eucerin Cream, Beiersdorf, Hamburg, Germany)

Petroleum-based ointment (Aquaphor, Beiersdorf, Hamburg, Germany)

Petroleum Jelly (Walgreens, Deerfield, IL)

Glycerol (Sigma G-9012, Sigma-Aldrich, St. Louis, MO)

Nylon nonwoven web (Cerex Advanced Fabrics, Cantonment, FL)

Hand warmer (Air-activated disposable warm pack, Heat Factory, Carlsbad, CA)

Alcohol pad (PDI Healthcare, Orangeburg, NY)

\section{RESULTS}

\section{Oxygen index}

This test is used to indicate a relative flammability, since most materials will burn at $100 \%$ 

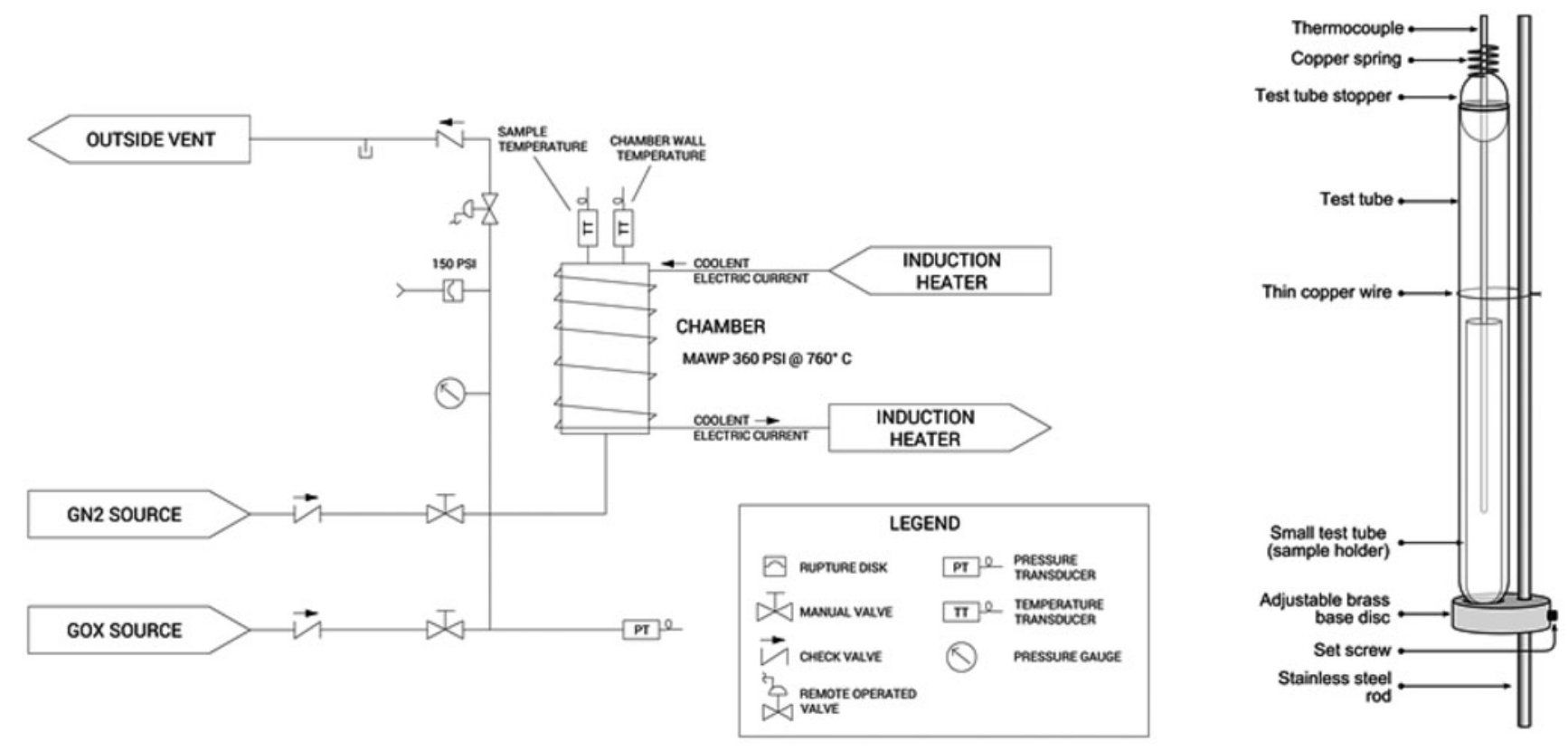

Figure 3. Left. AIT test system; Right. Test tube holder assembly. AIT, autogenous ignition temperature.

oxygen. Of the 44 materials tested in this assay, all but two materials exhibited an OI equal to or greater than a control material commonly used in HBO (gauze: 18\%). The two materials below gauze were at $17 \%$.

As examples, Fig. 4 illustrates gauze and Fig. 5 depicts a sample of clear plastic surgical tape, before and after the OI test. Figure 6 displays graphically the OI for all materials tested.

OI values were not achieved for Tegaderm ${ }^{\mathrm{TM}}$ Hydrogel Wound Filler or Steri-Strip ${ }^{\mathrm{TM}}$ Compound
Benzoin Tincture, as they did not burn in $100 \%$ oxygen, according to the ASTM G125 ${ }^{12}$ criterion. However, since these were liquid samples that were applied to a fiberglass substrate and allowed to dry, the results may not be directly comparable to the results obtained for the solid materials. The total mass of the liquid sample was significantly less than that of the solid samples. Further, the thickness of the dried liquid sample was significantly thin compared with the solid samples and compared with the fiberglass substrate. The fiberglass
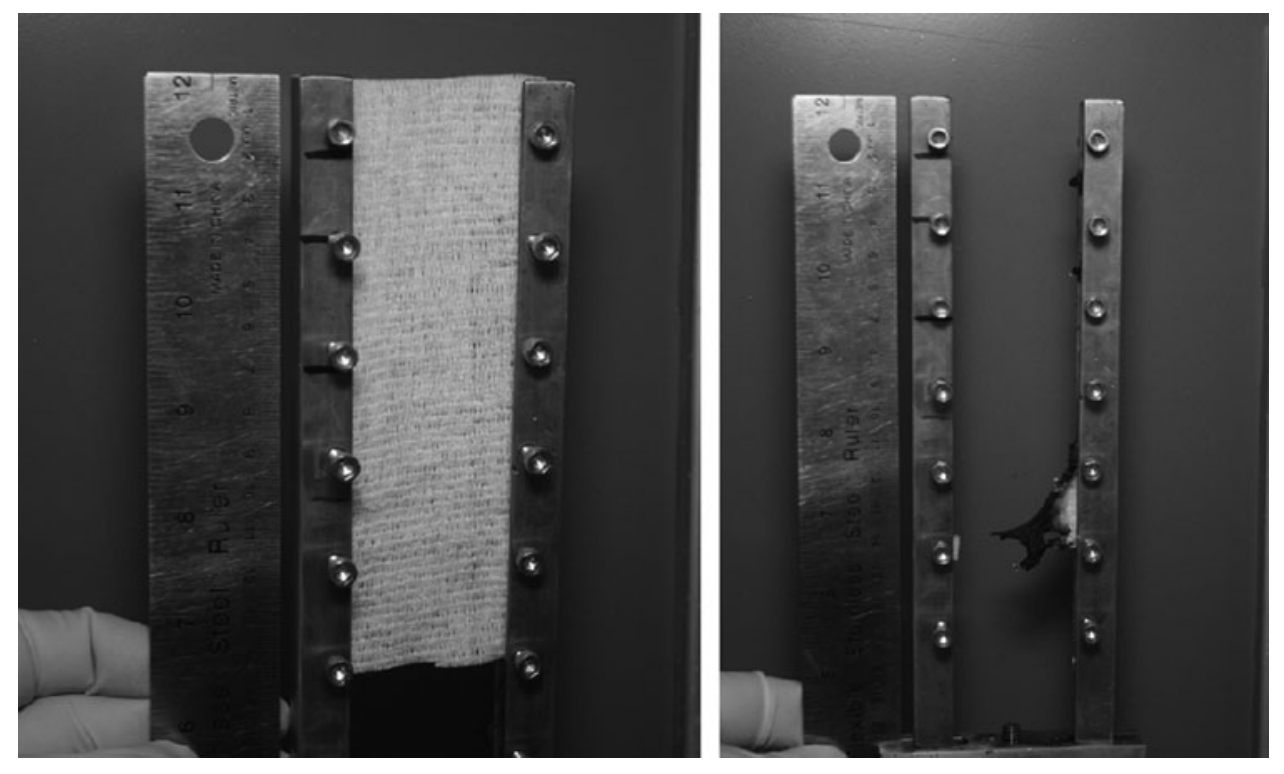

Figure 4. Pre- (left) and post- (right) test photos of gauze, 18\% oxygen. 

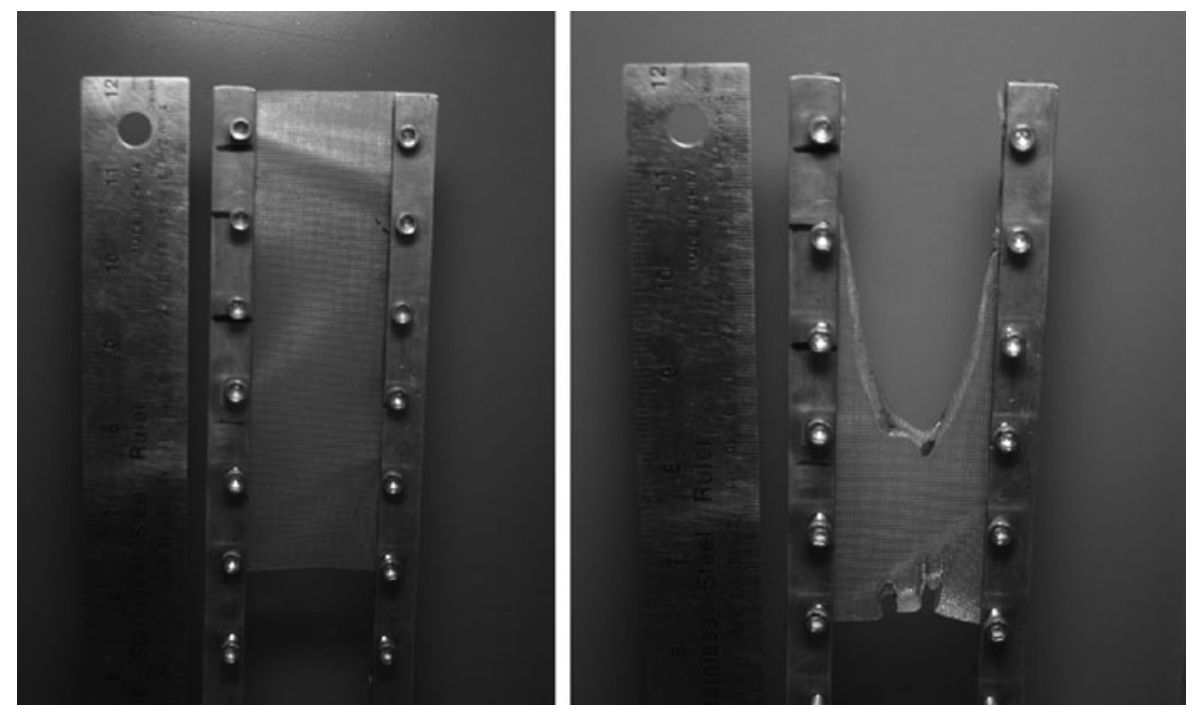

Figure 5. Pre- (left) and post- (right) test photos of transpore surgical tape, $21 \%$ oxygen.

substrate may have acted as a thermal sink preventing the combustion event from reaching selfsustained burning until the oxygen concentration was sufficient to provide the additional combustion energy required to sustain burning. The results indicated that, for all the products that exhibited an OI below $100 \%$, they would be expected to burn, if ignited, in $100 \%$ oxygen. This is consistent for most nonmetallic, organic materi- als. Further, historical testing has demonstrated that the OI typically reduces with an increasing oxygen pressure.

\section{Oxygen exposure}

The results of the $\mathrm{OE}$ testing indicated that none of the 44 materials tested in this assay selfignited within the $60^{\circ} \mathrm{C}, 3 \mathrm{~atm}$ pressurized oxygen atmosphere. The 44 materials were considered to

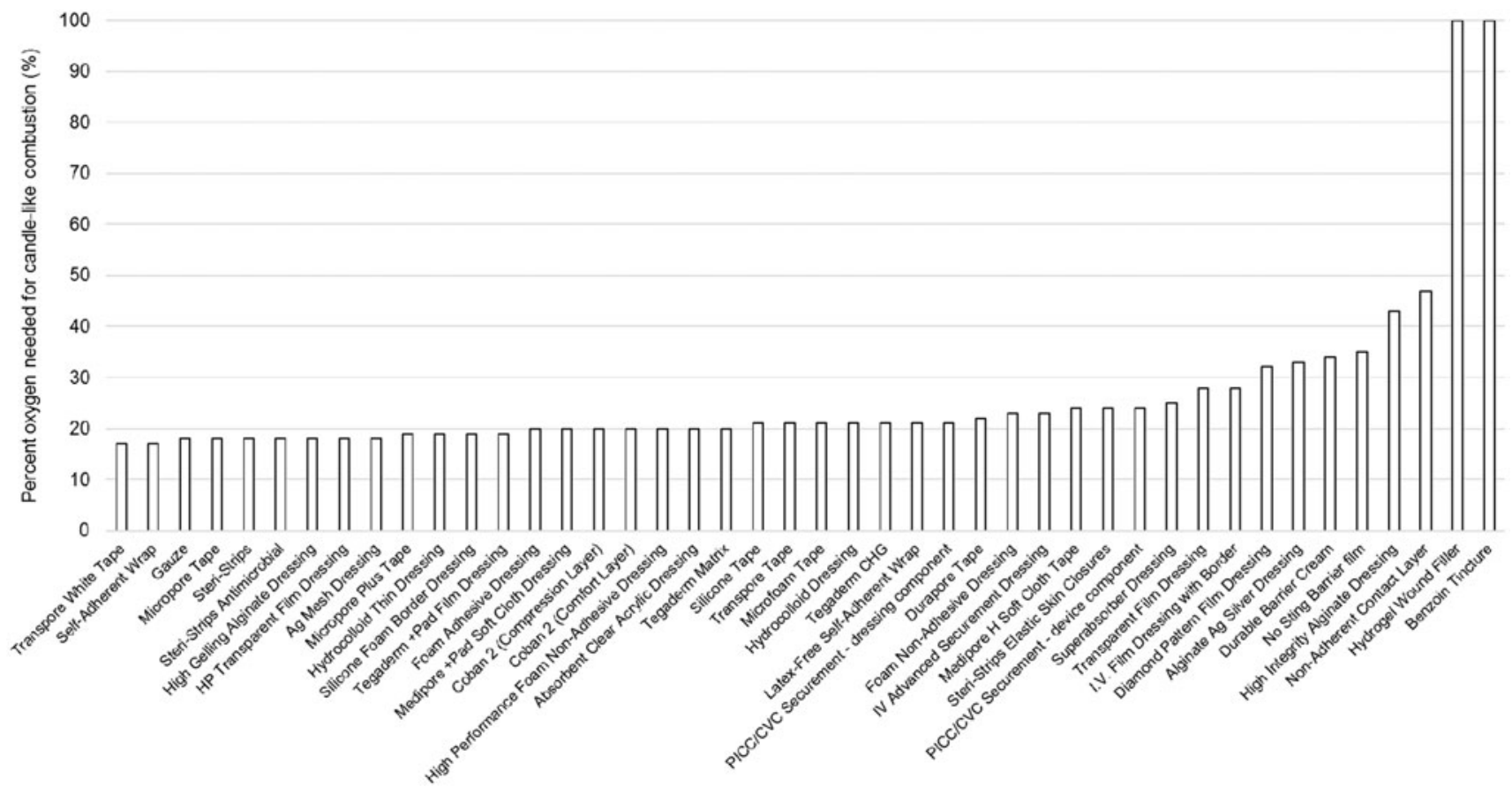

Figure 6. Ol values for each tested material, that is, how much oxygen must be present to ignite the product. On this graph, materials are sorted in order of increasing $0 \mathrm{O}$. 
exhibit a low probability of self-ignition and a high severity of ignition. This high level of severity is consistent for all nonmetallic materials that are exposed to HBO.

Temperature and pressure data remained relatively unchanged over the 6 -h test duration and were not characteristic of exothermic activity and/or a sample ignition event. When a test sample ignites, the ignition of the sample corresponds to a distinct temperature and pressure increase of the test chamber gas. This was not observed for any OE tests. No significant mass gains or losses were observed for the solid samples. For some of the samples (e.g., $3 \mathrm{M}^{\mathrm{TM}}$ Tegaderm $^{\mathrm{TM}}$ Hydrogel Wound Filler, $3 \mathrm{M}^{\mathrm{TM}}$ Cavilon $^{\mathrm{TM}}$ Durable Barrier Cream Fragrance Free, and $3 \mathrm{M}^{\mathrm{TM}}$ Steri-Strip ${ }^{\mathrm{TM}}$ Compound Benzoin Tincture), a mass loss was most likely due to liquid evaporating and off-gassing inside the test chamber. No differences were observed between the pre- and post-test appearance of the samples (data not shown).

\section{AUTOGENOUS IGNITION TEMPERATURE}

This test indicates a material's relative propensity for ignition. Ten solid wound care materials were tested, and the AIT for each material ranged from $138^{\circ} \mathrm{C}$ to $384^{\circ} \mathrm{C}$. Seven additional materials that are usually avoided in HBO chambers were tested (glycerin-based cream, petroleum-based ointment, glycerol, petroleum, alcohol pad, nylon, and a hand warmer). The AIT for those ranged from $146^{\circ} \mathrm{C}$ to $420^{\circ} \mathrm{C}$. Data obtained from testing were evaluated and analyzed to determine the most probable temperature of ignition by temperature and/or pressure response. Using the pressure signal to detect ignition was consistent with the experience and approach of another testing laboratory ${ }^{15}$ performing testing similar to ASTM G72 ${ }^{14}$ (2009). In certain tests where ignition was detected, multiple points of pressure oscillations and/or significant temperature rises were observed. This was consistent with secondary ignitions that can occur when intermediate flammable reaction species are created and/or complete combustion of the sample does not occur during the first ignition. In these tests, the lowest ignition temperature detected was reported as the AIT. Figure 7 displays the lowest AIT value for all materials tested.

\section{DISCUSSION}

Three tests were used to assess the oxygen compatibility of various materials that were likely to be present on patients treated in HBO chambers. The OI test allowed us to conclude that the materials tested were considered flammable in HBO environments. Therefore, the materials would be expected to burn, if ignited, in 100\% oxygen. This is true of most nonmetallic materials, and the values obtained were quite similar for most of the materials we tested. The OE test showed that the materials tested would not be expected to self-ignite at or below $60^{\circ} \mathrm{C}$ and $3 \mathrm{~atm}$. The AIT test indicated, for each material, the temperature at which it can

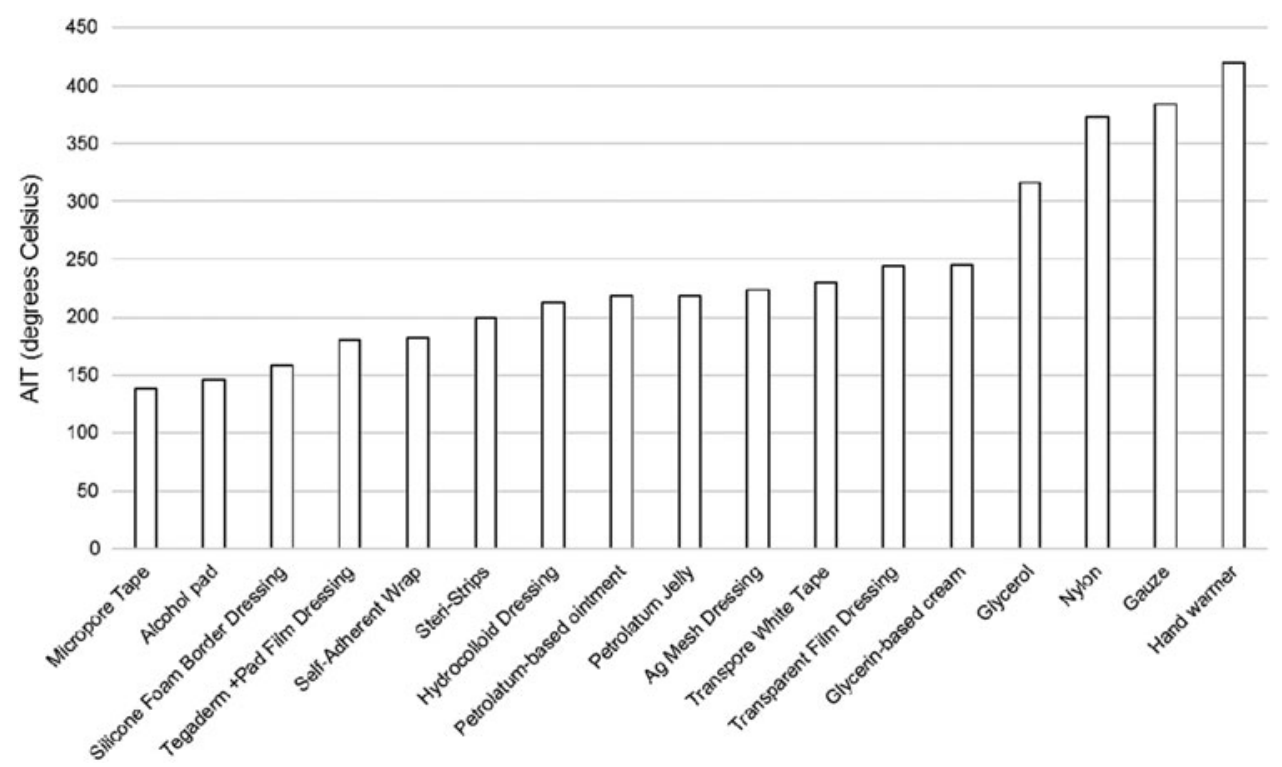

Figure 7. Lowest autogenous ignition temperature values for each tested material (degrees celsius). On this graph, materials are sorted in order of increasing AIT. 
burn under $\mathrm{HBO}$ conditions, with a lowest AIT ranging from $146^{\circ} \mathrm{C}$ to $420^{\circ} \mathrm{C}$.

The data suggest that of the three assays performed, the AIT provides better differentiation between the various materials. The OI test is less differentiating than the AIT because most materials will burn at $100 \%$ oxygen. The OE test was also not very differentiating because none of the materials tested self-ignited in the test conditions used. The AIT results showed a range of temperatures at which ignition occurred, providing more differentiation between materials. At the time of this testing work, this was not a standard test. Since this testing work was completed, ASTM G72 was revised and the latest version ${ }^{11}$ (2015) includes permissions for testing at lower pressures, such as $3 \mathrm{~atm}$, and faster temperature ramp rates, such as $100^{\circ} \mathrm{C} / \mathrm{min}$. Therefore, the AIT testing documented here is now consistent with ASTM G72-15. ${ }^{11}$ However, this new test standard does not include the specific direction to perform the testing with the two sample masses selected and the temperature ramp selected when testing at $\mathrm{HBO}$ conditions. Further, the HBO industry has yet to establish a safety margin or pass/fail criteria for this specific test, so the application of this data should be approached cautiously. ASTM $\mathrm{G} 63^{16}$ recommends a $100^{\circ} \mathrm{C}$ safety margin between the AIT of a material and the maximum service temperature. The materials were intended for application on the human body, which is typically at a maximum temperature of $\sim 38^{\circ} \mathrm{C}$. Using the ASTM G63 ${ }^{16}$ margin, the $138^{\circ} \mathrm{C}$ result would be equal to this margin. This data application example considered only the ignition mechanism associated with heat conduction from the human body, but it did not address other potential ignition mechanisms such as electrostatic discharge. Whether this margin is appropriate for HBO AITs is a question that the industry needs to evaluate if a new standard is developed.

Our results show that some products that are currently avoided in HBO (e.g., nylon, alcohol pads, hand warmers) have similar AIT numbers than other products with a successful history in HBO. The results could appear to suggest that more products could possibly be allowed in the HBO chambers; however, the AIT test does not indicate the spark-forming potential of materials. For example, nylon may help generate a spark (through static electricity), but based on its high AIT result, it is unlikely to be the first material to ignite and serve as fuel. Alcohol pads would pro- duce highly flammable vapors that would be expected to ignite by electrostatic discharge. In addition, the hand warmer gave a relatively high AIT value, but this type of device has been responsible for a HBO chamber fire in the past. ${ }^{5}$ The AIT results of the hand warmer may suggest the hand warmer materials were not the first ignited fuel but produced the thermal energy to ignite a proximate and more flammable material. Therefore, in no way should hand warmers be permitted in hyperbaric chambers. Based on our results, we suggest the need to design another test, relevant to HBO conditions, to measure the risk of electrostatic discharge associated with various materials.

\section{INNOVATION}

This work provides useful new data and recommendations to help develop a needed new standard approach for evaluating the HBO compatibility of wound care products and medical devices, in general, to ensure safety for patients and clinicians. The development of a test to measure the risk of electrostatic discharge of materials in conditions that are relevant to $\mathrm{HBO}$ environments would be very useful to supplement the data from other testing options such as AIT. The HBO industry needs to make decisions on acceptable threshold values for materials deemed safe for use.

\section{ACKNOWLEDGMENTS AND FUNDING SOURCES}

Stéphanie F. Bernatchez and Joseph Tucker are employees of $3 \mathrm{M}$. $3 \mathrm{M}$ is a manufacturer of wound care products. Gwenael Chiffoleau is an employee of WHA International, Inc. WHA is an independent, internationally recognized research institution that specializes in oxygen compatibility testing, oxygen fire investigation and forensics, oxygen hazards training, and oxygen system designs. 


\section{AUTHOR DISCLOSURE AND GHOST WRITING}

S.F. Bernatchez and J. Tucker are employees of $3 \mathrm{M}$. G. Chiffoleau is an employee of WHA International, Inc. All authors contributed toward writing this article, and no ghost writers were used to write this article.

\section{ABOUT THE AUTHORS}

Stéphanie F. Bernatchez, PhD, received her $\mathrm{PhD}$ in Interdisciplinary Sciences from the University of Geneva, Switzerland. She currently resides in Minnesota and works for $3 \mathrm{M}$. Her work at $3 \mathrm{M}$ has included research and development in the area of advanced wound care using in vitro and in vivo assays, as well as clinical research work. Joseph Tucker, BA, received his degree in Natural Science from St. John's University, Collegeville, MN. He currently resides in Minnesota and works for $3 \mathrm{M}$. Gwenael Chiffoleau, $\mathbf{P h D}$, received his $\mathrm{PhD}$ in Aerospace Engineering from the University of Queensland, Australia. At WHA International, Gwenael leads research and test development involving flammability and ignition studies of materials and components in oxygen.

\section{REFERENCES}

1. Weaver LK. Hyperbaric Oxygen Therapy Indications, 13th ed. Undersea and Hyperbaric Medical Society. North Palm Beach, FL: Best Publishing Company, 2014

2. Ozturk F, Ermertcan AT, Inanir I. Hyperbaric oxygen therapy for the management of chronic wounds. Cutan Ocul Toxicol 2013;32:72-77.

3. Goldstein LJ. Hyperbaric oxygen for chronic wounds. Dermatol Ther 2013;26:207-214.

4. Simini B. Fire fuels concerns over hyperbaric oxygen facilities. Lancet 1997;350:1375.

5. Sheffield PJ, Desautels DA. Hyperbaric and hypobaric chamber fires: a 73-year analysis. Undersea Hyperb Med 1997;24:153-164.

6. Colvin AP. Fire-safety standards for hyperbaric oxygen facilities. Lancet 1998;351:69.

7. NFPA. Health Care Facilities Code Handbook. Health Care Facilities Code Handbook, 9th ed. Quincy, Massachusetts: National Fire Protection Association, 2012

8. McCord DE, Newton BE, Fore J, Chiffoleau G. The selection of skin care products for use in hyperbaric chamber may depend on flammability ac- ceptability indices score. Adv Skin Wound Care 2008;21:79-84.

9. Raleigh G, Rivard R, Fabus S. Air-activated chemical warming devices: effects of oxygen and pressure. Undersea Hyperb Med 2005;32:445449.

10. Cony P, Mathieu D, Houman R, Macchi JP, Dubois $P$, Wisson F. Méthodologie d'intégration de dispositifs médicaux en milieu hyperbare. Itbm-Rbm 2005;26:363-370.

11. ASTM. ASTM G72/G72M-15: Standard Test Method for Autogenous Ignition Temperature of Liquids and Solids in a High-Pressure OxygenEnriched Environment. West Conshohocken, PA (www.astm.org): ASTM International, 2015.

12. ASTM. ASTM G125-00: Standard Test Method for Measuring Liquid and Solid Material Fire Limits in Gaseous Oxidants. West Conshohocken, PA (www.astm.org): ASTM International, 2008.

13. ASTM. ASTM G124-10: Standard Test Method for Determining the Combustion Behavior of Metallic Materials in Oxygen-Enriched Atmospheres. West Conshohocken, PA (www.astm.org): ASTM International, 2010.
14. ASTM. ASTM G72/G72M-09: Standard Test Method for Autogenous Ignition Temperature of Liquids and Solids in a High-Pressure OxygenEnriched Environment. West Conshohocken, PA (www.astm.org): ASTM International, 2009.

15. Wegener W, Binder C, Hengstenberg P, Herrmann $K P$, Weinert D. Tests to evaluate the suitability of materials for oxygen service. In: Schroll DW, ed. Flammability and Sensitivity of Materials in Oxygen-Enriched Atmospheres, Third Volume, ASTM STP 986. Philadelphia: American Society for Testing and Materials; 1988.

16. ASTM. ASTM G63-15: Standard Guide for Evaluating Nonmetallic Materials for Oxygen Service. West Conshohocken, PA (www.astm.org): ASTM International, 2015.

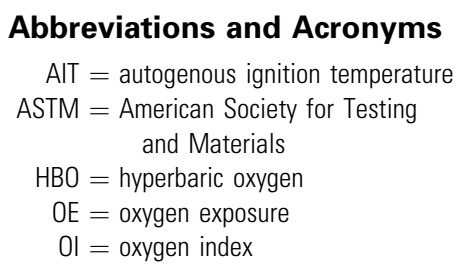

